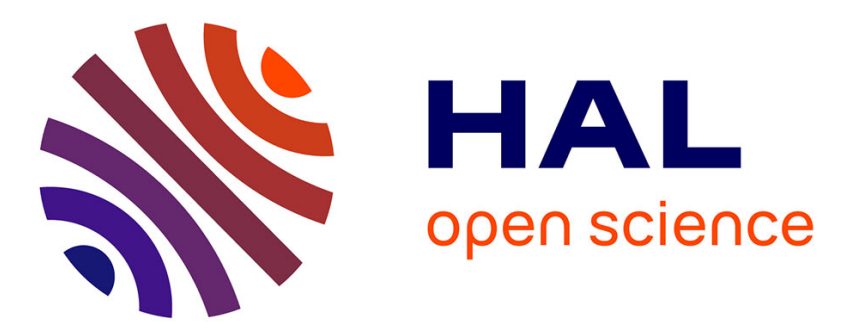

\title{
13C-dating, the first method to calculate the relative age of molecular substance homologues in soil
}

\author{
Eric Lichtfouse
}

\section{To cite this version:}

Eric Lichtfouse. 13C-dating, the first method to calculate the relative age of molecular substance homologues in soil. Environmental Chemistry Letters, 2012, 10 (1), pp.97-103. 10.1007/s10311-0110334-2 . hal-00674221

\section{HAL Id: hal-00674221 \\ https://hal.science/hal-00674221}

Submitted on 26 Feb 2012

HAL is a multi-disciplinary open access archive for the deposit and dissemination of scientific research documents, whether they are published or not. The documents may come from teaching and research institutions in France or abroad, or from public or private research centers.
L'archive ouverte pluridisciplinaire HAL, est destinée au dépôt et à la diffusion de documents scientifiques de niveau recherche, publiés ou non, émanant des établissements d'enseignement et de recherche français ou étrangers, des laboratoires publics ou privés. 
Revised version

Environmental Chemistry Letters 10, 97-103, 2012. doi : 10.1007/s10311-011-0334-2

\title{
${ }^{13} \mathrm{C}$-dating, the first method to calculate the relative age of molecular substance homologues in soil
}

\author{
Eric Lichtfouse \\ INRA, UMR1347Agroécologie, AgroSup/INRA/uB, BP 86510, 21065 Dijon Cedex, France. \\ E-mail: Eric.Lichtfouse@dijon.inra.fr
}

\begin{abstract}
This article reports the design of ${ }^{13} \mathrm{C}$-dating, the first method to calculate the relative age ofmolecular substance homologues occurring in fractions from the same soil sample. Soil is a major carbon pool impacting modern climate by $\mathrm{CO}_{2}$ release and uptake.Molecular substances that sequester carbon in soils are poorly known due to the absence of methodsto study molecular-level $\mathrm{C}$ dynamics over agricultural time scales, e.g. 0-200 years. Here I design a method to calculate the relative age of the plant-derived $\mathrm{C}_{31} n$-alkane occurring in 6 fractions from a soil sample naturally ${ }^{13} \mathrm{C}$-labelled by maize cropping during 23 years. Soil fractions arethe bulk soil extract, two humin-encapsulated fractions and threeparticle-size fractions.Results show that $\mathrm{C}_{31} n$-alkane homologueshave relative ages ranging from -6.7 years for the humin-encapsulated homologue to +25.1 years for the $200-2000 \mu \mathrm{m}$ fraction homologue. Such a wide variationof 31.8 years evidences temporal pools of molecular substances in soil. This finding also reveals that physical encapsulation can strikingly change the dynamics of a single molecular substance. ${ }^{13} \mathrm{C}$-datingthus allowsto assess the carbon storage potential of molecular substances from crop soils. Such knowledge will help to identify molecular compounds, associated soil pools and agricultural practices that favour carbon sequestration. ${ }^{13} \mathrm{C}$-dating is further applicable to any environmental sample containing organic matter subjected to a ${ }^{13} \mathrm{C}$ isotope shift with time. ${ }^{13} \mathrm{C}$-dating will also help to study the sequestration and delayed release of chemicals in various disciplines, such as pollutants in environmental sciences, pharmaceuticals in medicine, and nutrients in food science.
\end{abstract}

Keywords Soilorganicmatter; Humin; ${ }^{13} \mathrm{C}$; Csequestration; Maizewax n-alkane; Agriculture; Datingmethod ; Physicalsequestration ; Encapsulation ; Pollutants ; Pharmaceuticals ; Foodscience

\footnotetext{
* Editor-in-Chief, Agronomy for Sustainable Development (http://www.springer.com/13593), Sustainable Agriculture Reviews (http://www.springer.com/series/8380), Environmental Chemistry Letters (http://www.springerlink.com/content/110367). Books: http://www.springer.com, Publications: http://hal.archives-ouvertes.fr, http://www.researcherid.com/rid/F-4759-2011. CV: http://www.linkedin.com/pub/eric-lichtfouse/19/493/720, http://www.viadeo.com/profile/002bhqrw3yisaw8/en.

Presentations: http://www.slideshare.net/lichtfouse/presentations
} 


\section{Introduction}

\section{Molecular issues}

Soil is a major carbon pool impacting climate change by $\mathrm{CO}_{2}$ release and uptake (Lal, 2010, Stavi and Lal, 2011, Lichtfouse et al. 2009, 2010, 2011). Agricultural practices can either sequester or deplete soil carbon in the long run (Benbi and Brar, 2009, Hazarika et al. 2009, Doumbia et al. 2009, Halberg et al. 2010, Novak and Fiorelli, 2010, Pati et al., 2010, Lichtfouse et al., 2011).Geoengineering using for instance biochar addition to soil is a potential technique to sequester soil carbon and in turn decrease atmospheric $\mathrm{CO}_{2}$ levels (Sohi et al. 2010). However mechanisms that control carbon sequestration are not fully understood because knowledge of thedynamics ofmolecularsubstances occurring in dead organic matter is scarce (Marschner et al., 2008). Dead matter indeed contain very complex mixtures of organic substancesinherited from the decay of living matter over short to long time periods (Schnitzer 1991, Hedges et al., 2000, Ohkouchia and Eglinton, 2008). In soils, although ${ }^{14} \mathrm{C}$-dating of bulk carbon(Wan et al., 1996) suggests the existence of organic substances agedup to several thousand years, dynamics at the molecular level are poorly known (Lichtfouse, 1995, 1997, 1999, Lichtfouse et al., 1998a,b,Hedges and Oades, 1997, Bull et al. 2000, Gleixner et al., 2002, Wiesenberg et al., 2004, Freier et al., 2010, Rubino et al., 2010). Such knowledge would help to define agricultural and land management practices that will favour carbon sequestration and, in turn, offset global warming.

\section{Sequestration in temporal pools}

Sequestration of an individual substance in different pools of a same sample is a poorly known phenomenon despite major potential implications for pollutant bioavailability and plant nutrient release (Figure 1) (Kubicki and Apitz, 1999, Sutton and Sposito, 2005). Given the extreme complexity of the soil matrix, individual substance homologues may indeed occur in the same soil sample within different physical and temporal pools, and thus canhave various ages and turnovers (Lichtfouse, 1999). For instance a free substance should be younger than the bound homologue encapsulated in humin, the macromolecular organic network of soils. A such hypothesis stems from reports showing for example the unexpected preservation of proteins in sediments (Knicker and Hatcher, 1997). The existence of temporal pools of molecular substances is of fundamental importance to understand the mechanisms of carbon cycling at the molecular level. The existence of temporal pools is also of applied importance to identify which individual substances and associated pools contribute to carbon sequestration. A suitable method is therefore necessary to assess the relative age of individual substances.

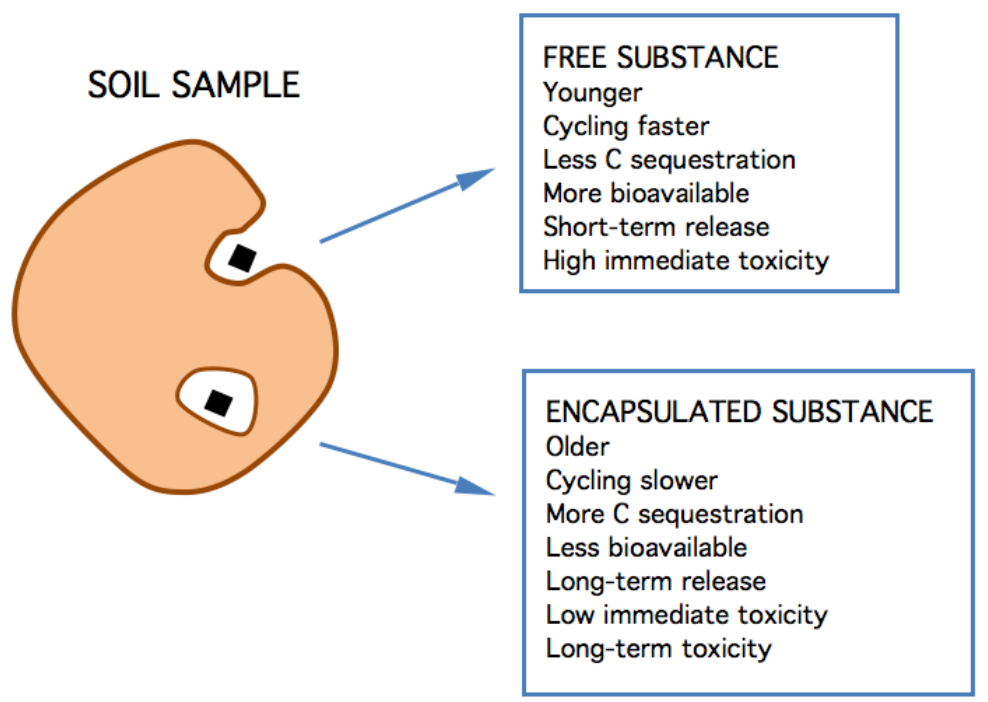

Figure 1. Encapsulation of molecular organic substances in soil. This scheme shows the consequences of physical encapsulation on the behaviour of organic substance homologues. Such consequences are relevant for carbon sequestration, plant nutrient storage and long-term pollutant release in waters, for example. The concept of encapsulation is also relevant for the delayed release of encapsulated pharmaceuticals and food substances (Mishra et al., 2010, Fang and Bhandari 2010). 


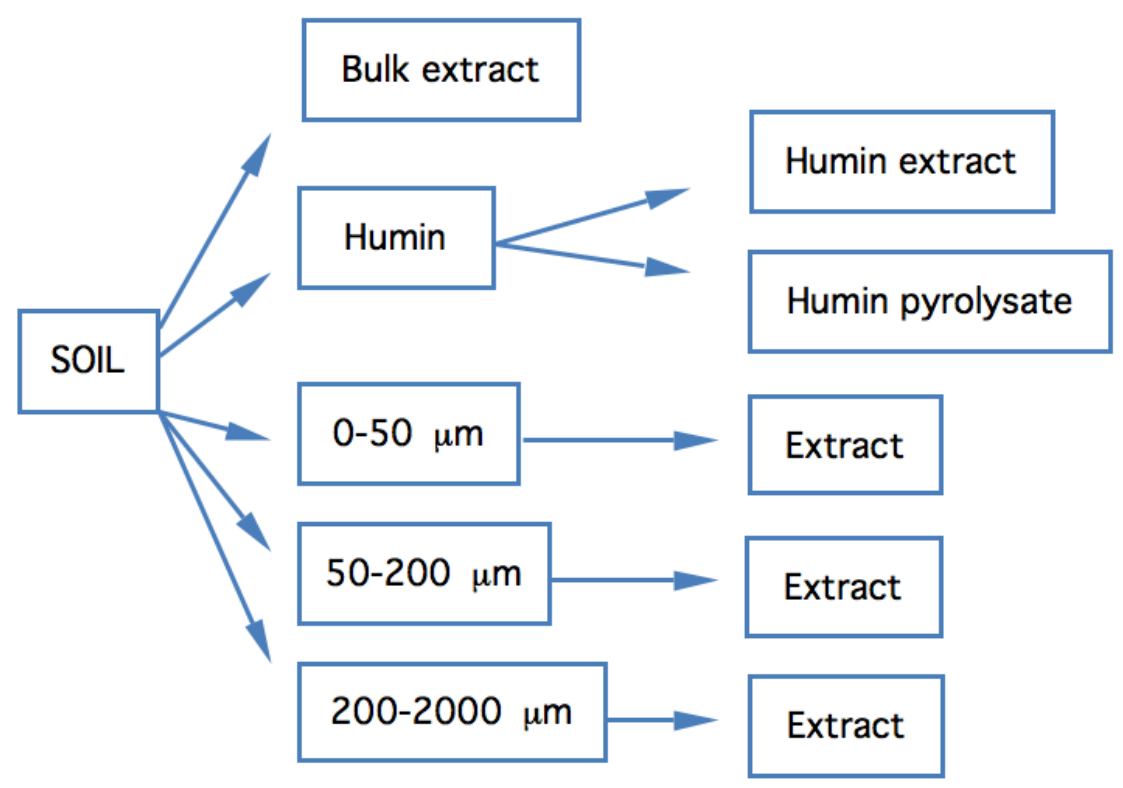

\begin{tabular}{lllll}
\hline Fractions & $\begin{array}{l}\boldsymbol{\delta}^{13} \mathbf{C} \\
(\%)\end{array}$ & $\begin{array}{l}\text { Maize-C } \\
(\%)\end{array}$ & $\begin{array}{l}\mathbf{t}_{1} \\
(\text { years })\end{array}$ & $\begin{array}{l}\text { Relative age } \\
\text { (years) }\end{array}$ \\
\hline Bulk soil extraction $^{\text {con }}$ & $-28.1^{\mathrm{c}}$ & 50.33 & 23 & 0 \\
Humin-encapsulated $^{\mathrm{a}}$ & $-29.7^{\mathrm{c}}$ & 39.74 & 16.3 & -6.7 \\
Humin-encapsulated $^{\mathrm{b}}$ & $-29.7^{\mathrm{c}}$ & 39.74 & 16.3 & -6.7 \\
$0-50 \mu \mathrm{m}$ fraction & $-27.3^{\mathrm{c}}$ & 55.63 & 26.2 & +3.2 \\
$50-200 \mu \mathrm{m}$ fraction & $-24.3^{\mathrm{c}}$ & 74.50 & 44.1 & +21.1 \\
$200-2000 \mu \mathrm{m}$ fraction & $-24.0^{\mathrm{c}}$ & 77.48 & 48.1 & +25.1 \\
\hline
\end{tabular}

a) $\mathrm{C}_{31} n$-alkane homologue from the humin extract, b) $\mathrm{C}_{31} n$-alkane homologue from the humin pyrolysate, c) data from Lichtfouse 1995, 1997, 1999, Lichtfouse et al. 1998b, Cayet and Lichtfouse, 2001. A possible pyrolytic carbon contribution to the humin-encapsulated $\mathrm{C}_{31} n$ alkane released by pyrolysis (b) can be excluded as explained previously (Lichtfouse et al. 1998a,b). Indeed gas chromatography analysis of the pyrolysate alkane/alkene fraction show that $\mathrm{C}_{27}-\mathrm{C}_{33} n$-alkanes have a strong odd-number predominance, typical of plant waxes, without $n$-alk-1-ene homologues typical of pyrolytic products (Lichtfouse et al. 1998a). Whereas $\mathrm{C}_{11}-\mathrm{C}_{26}$ show no odd/even predominance and have $n$-alk-1-ene homologues typical of pyrolytic products. In other words, pyrolysis is a means to release compounds that are physically encapsulated, that is without strong chemical bonds. Here the trick is to find a means to distinguish pyrolytic versus encapsulated homologues.

Figure 2. Top: fractionation of a soil sample into 6 fractions containing plant-derived $n$-alkanes. Bottom: relative age of soil $\mathrm{C}_{31} n$-alkane homologues 
Dating at the molecular level

${ }^{14} \mathrm{C}$-dating can date organic matter agedfrom hundreds to thousands of years, and has been successfully applied at the molecular level in sediments (Pearson and Eglinton, 2000, Pearson et al., 2001, Ohkouchia and Eglinton, 2008). Nonetheless ${ }^{14} \mathrm{C}$-dating is less suitable to study the turnover of organic matter over short time periods relevant to agriculture and climate change, e.g. from 0 to 200 years. This issue is due both to the global ${ }^{14} \mathrm{C}$ contamination of modern samples by atomic bomb testing around 1950 (Harkness et al., 1986) and to the higher standard deviation of ${ }^{14} \mathrm{C}$-dating versus the rapid turnover of recent organic material in soils(Trumbore, 2000). Alternatively, ${ }^{14} \mathrm{C}$-spiking of tagged compounds is another technique used for instance to study pesticide biodegradation(Barriuso et al., 2008). However ${ }^{14} \mathrm{C}$-spiking is less representativeof native compounds because spiking in itself does not represent the natural behaviour of native compounds such as plant-derived substances found in crop soils. Therefore a method is needed to assess the dynamics of individualsoil organic substances over short time periods. Here I report a novel method, named ${ }^{13} \mathrm{C}$-dating, designed by conceptualisingprevious findings(Lichtfouse 1995, 1997, 1999, Lichtfouse et al. 1998b, Cayet and Lichtfouse, 2001). ${ }^{13} \mathrm{C}$-dating allows to measure the relative age of organic substances from dead organic matter that has been ${ }^{13} \mathrm{C}$-labelled at natural abundance.

\section{Experimental}

Detailed experimental procedures and data are given elsewhere (Lichtfouse 1995, 1997, 1999, Lichtfouse et al. 1998b, Cayet and Lichtfouse, 2001). Briefly, soils were sampled in an experimental maize crop field in France. Cropping maize, a naturally ${ }^{13} \mathrm{C}$-enriched plant, is a means to follow the fate of plant carbon into soil organic matter. In this article I discuss data from a soil sample cultivated 23 years with maize. The $\mathrm{C}_{31}$ soil $n$ alkane, a compound derived from plant waxes, was analysed in 6fractionsfrom the same soil sample. Fractions are the bulk soil extract; the humin-encapsulated $n$-alkane fraction released either by extraction or pyrolysis; and $n$-alkanes in 0-50 $\mu \mathrm{m}, 50-100 \mu \mathrm{m}$, and 200-2000 $\mu \mathrm{m}$ particle-size fractions (Figure 2).

The bulk soil extract was obtained by $\mathrm{CHCl}_{3}-\mathrm{MeOH} 3 / 1$ (v/v) extraction,then was fractionated by several steps of silica gel chromatography to yield an alkane fraction suitable for ${ }^{13} \mathrm{C}$ analysis (Lichtfouse, 1997). Humin was obtained by treatment of the $\mathrm{CHCl}_{3}-\mathrm{MeOH}$ pre-extracted soil sample by $\mathrm{HF} / \mathrm{HCl}$ to remove minerals (Lichtfouse et al., 1998b). Two pools of encapsulated alkanes were isolated from humin: a pool of alkanes occurring in the $\mathrm{CHCl}_{3}-\mathrm{MeOH}$ humin extract, and a pool released by pyrolysis of the $\mathrm{CHCl}_{3}-\mathrm{MeOH}$ pre-extracted humin. Particle-size fractions were isolated from the soil sample by sieving in water followed by density separation (Cayet and Lichtfouse, 2001). Alkane fractions were obtained from particle-size fractions by $\mathrm{CHCl}_{3}-\mathrm{MeOH}$ extraction followed by several steps of silica gel chromatography. Alkane fractions were then analysed for $\delta^{13} \mathrm{C}$ values by gas chromatography-combustion-isotope ratio mass spectrometry (GC-C-IRMS). I reviewed the main applications of compound specific isotope analysis (Lichtfouse, 2000).

\section{Results and discussion}

Turnover of soil molecular substances

The principle of ${ }^{13} \mathrm{C}$-dating at the molecular level is built on previous datafrom ${ }^{13} \mathrm{C}$-labelling cultivation experiments (Lichtfouse 1995, 1997, 1999, Lichtfouse et al. 1998b, Cayet and Lichtfouse, 2001). Specifically, cropping maize, a naturally ${ }^{13} \mathrm{C}$-enriched $\mathrm{C}_{4}$ plant, on soils previously cultivated with naturally ${ }^{13} \mathrm{C}$-depleted $\mathrm{C}_{3}$ plants, e.g. wheat, slowly incorporates ${ }^{13} \mathrm{C}$-enriched plant matter in soil (Figure 3). As a consequence the $\mathrm{C}_{31}$ maize leaf wax $n$-alkane of $\delta^{13} \mathrm{C}-20.6 \%$ is progressively introduced into the soil and mix with the ${ }^{13} \mathrm{C}$-depleted $\mathrm{C}_{31}$ soil $n$-alkane of $\delta^{13} \mathrm{C}-35.7 \%$. The $\delta^{13} \mathrm{C}$ value of soil $\mathrm{C}_{31} n$-alkane thus increases from $-35.7 \%$ to $-28.1 \%$ after 23 years of maize cropping (Lichtfouse 1995). A such isotope shift allows to calculate the percentage of maize-derived carbon within the soil $\mathrm{C}_{31} n$-alkane:

$$
\text { Equation } 1 \quad \mathrm{M}=100 .\left(\delta-\delta_{0}\right) /\left(\delta_{\mathrm{m}}-\delta_{0}\right)
$$


Where $\mathrm{M}$ isthe percentage of maize-derived $\mathrm{C}$ in the soil substance, $\delta$ denotes the $\delta^{13} \mathrm{C}$ value of the soil substance at a given time of maize cultivation, $\delta_{0}$ depicts the $\delta^{13} \mathrm{C}$ value of the soil substance before maize cultivation $(-35.7 \%)$, and $\delta_{\mathrm{m}}$ refers to the $\delta^{13} \mathrm{C}$ value of the maize substance $(-20.6 \%)$. This calculation shows that the soil $\mathrm{C}_{31} n$-alkane contains $50.3 \%$ of maize-derived carbon after 23 years of calculation. Therefore about half of the soil $\mathrm{C}_{31} n$-alkane is renewed after 23 years. The dynamics of the soil $\mathrm{C}_{31} n$-alkane can be further modelledusing a first-order kinetic law(Lichtfouse 1997):

$$
\text { Equation } 2 \quad \mathrm{M}=100 \times\left(1-\exp \left(-0.031 \mathrm{t}_{1}\right)\right)
$$

Where $\mathrm{M}$ refers to the percentage of maize-derived $\mathrm{C}$ in the soil substance and $\mathrm{t}_{1}$ denotes the time of maize cultivation in years. Accordingly the complete renewal of $99 \%$ of the soil $\mathrm{C}_{31} n$-alkane will last 148 years. This finding represented the first determination of the turnover of soil carbon at the molecular level(Lichtfouse 1997).
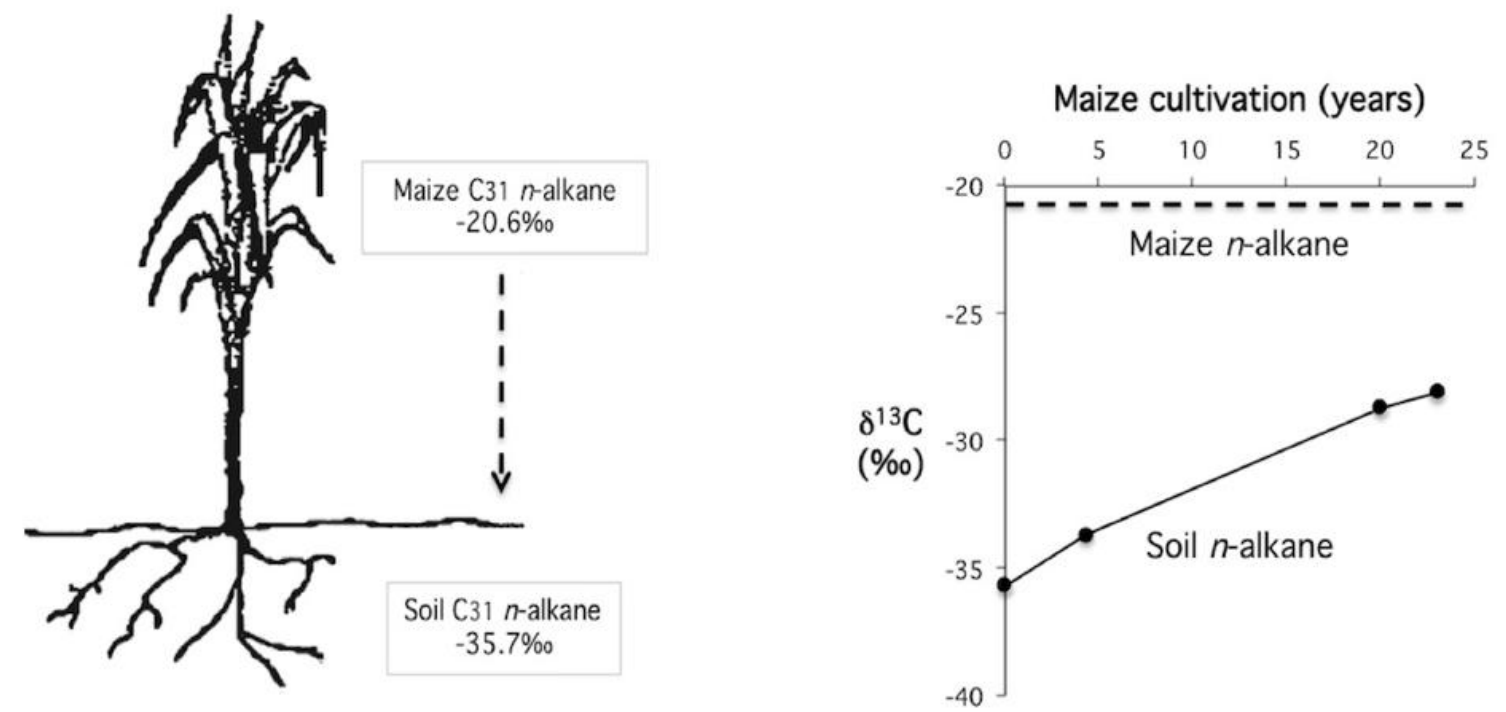

Figure 3. Labelling individual soil organic compounds at natural abundance.Maize (Zea mays), a naturally ${ }^{13} \mathrm{C}$-enriched plant, is cultivated on a soil which was previously cultivated with ${ }^{13} \mathrm{C}$-depleted plants. The $\mathrm{C}_{31}$ leaf wax $n$-alkane of $\delta^{13} \mathrm{C}-20.6 \%$, is progressively introduced into the soil and mix with the ${ }^{13} \mathrm{C}$-depleted $\mathrm{C}_{31}$ soil $n$-alkane $\left(\delta^{13} \mathrm{C}-35.7 \%\right.$ ). The isotope value of the soil $n$-alkane therefore increases over years of maize cultivation (Lichtfouse, 1995).

Physical encapsulation of substance homologues

Access to the turnover further allows to measure the relative age of substance homologues occurring in 6 fractions from the same soil sample (Figure 2). The free $\mathrm{C}_{31} n$-alkane is isolated from the bulk soil by solvent extraction (Lichtfouse 1995, 1997). The encapsulated $C_{31} n$-alkane homologue is isolated from humin either by extraction or pyrolysis (Lichtfouse et al. 1998b, Lichtfouse 1999). $\mathrm{C}_{31} n$-alkane homologues are also extracted from soil particle-size fractions (Cayet and Lichtfouse, 2001). Previous occurrence of substance homologues in compartments of soils and modern sediments were suspected but not proven due to the lack of method allowing to distinguish compounds of identicalmolecular structure. This issue is solved here by measuringdifferent ${ }^{13} \mathrm{C}$ isotope ratios for $\mathrm{C}_{31} n$-alkane homologues occurring in 6fractions from a soil cultivated 23 years with maize (Figure 2).

Results show a wide range of $\mathrm{C}_{31} n$-alkane $\delta^{13} \mathrm{C}$ values from $-29.7 \%$ for the humin encapsulated homologue to $-24.0 \%$ for the homologue in the $200-2000 \mu \mathrm{m}$ particle-size fraction. As a consequence the oldest $\mathrm{C}_{31} n$ alkane homologue is encapsulated into humin and contains only $39.74 \%$ of maize $\mathrm{C}$, whereas the youngest $\mathrm{C}_{31} n$-alkane homologue occurs in the $200-2000 \mu \mathrm{m}$ particle-size fraction and contains $77.48 \%$ of maize $\mathrm{C}$. Such a large difference demonstrate unambiguously for the first time that the turnover of an individual substance vary widely depending on its physical localisation within the soil matrix. This finding implies also that the stability and degradation of substances is soils cannot be explained solely by their molecular 
structure, but should take physical protection into account. Physical encapsulation of organic molecules was previously hypothesised but definitive proof was lacking. Here the lower maize-C content of $n$-alkane homologues evidence the mechanism of physical encapsulation at the molecular level.

A possible effect of biodegradation on the ${ }^{13} \mathrm{C}$-dating method should be considered. Indeed, in theory, free compounds should be more accessible to microbes and should thus be more biodegraded that bound compounds. If biodegradation occurs, then the $\delta^{13} \mathrm{C}$ values may be changed if biodegradation induces ${ }^{13} \mathrm{C} /{ }^{12} \mathrm{C}$ isotope fractionation. However petroleum biodegradation experiments using microbial communities show the absence of $\delta^{13} \mathrm{C}$ shift of alkanes (Mazeas et al. 2002). A further comparison of petroleum samples of increasing degree of biodegradation also shows the absence of ${ }^{13} \mathrm{C}$ isotope shifts of $n$-alkanes (Sun et al., 2005). In addition a 23-year decomposition experiment of Calluna vulgaris shoots using litter-bags buried in a peat bog shows the absence of $\delta^{13} \mathrm{C}$ shifts of $n$-alkanes despite $90 \%$ weight loss of the plant shoot biomass (Huang et al. 1997). To conclude, a possible effect of biodegradation on the ${ }^{13} \mathrm{C}$-dating method due to a ${ }^{13} \mathrm{C}$ shift can be reasonably excluded for the results of this article.

\section{Relative age}

The relative age of $\mathrm{C}_{31} n$-alkane homologues occurring in different fractions from the same soil can be calculated according to:

\section{Equation 3 Relative age $=\mathrm{t}_{1}-\mathrm{t}_{2}$}

Where $t_{1}$ refers to the time of maize cultivation calculated using kinetics of maize $\mathrm{C}$ content in the free $\mathrm{C}_{31} n$ alkane from the bulk soil (Equation 2). $t_{2}$ denotes the time of maize cultivation of the soil sample, of 23 years in our example (Figure 2). In other words $t_{1}$ represents the cultivation time at which the $C_{31} n$-alkane from soil fractions, e.g. humin-encapsulated and particle sizes, would have the same maize $\mathrm{C}$ content as the free $\mathrm{C}_{31} n$-alkane from the bulk soil extraction (see arrows inFigure 4). For instance the humin-encapsulated $\mathrm{C}_{31} n$ alkane from the soil cultivated 23 years with maize has a maize $\mathrm{C}$ content equal to free homologue from the soil cultivated 16.3 years, thus yielding a relative age of -6.7 years. Similarly the $\mathrm{C}_{31} n$-alkane from the 200 $2000 \mu \mathrm{m}$ particle-size fraction of the soil cultivated 23 years with maize has a maize $\mathrm{C}$ content equal to free homologue from the soil cultivated 48.1 years, thus yielding a relative age of +25.1 years. Those findings bring unambiguous evidence for temporal pools of individual substance homologues in soil(Lichtfouse 1999).The wide age difference of 31.8 years between the two $n$-alkane fractions reveals that physical encapsulation can strikingly change the dynamics of a molecular substance. To conclude, ${ }^{13} \mathrm{C}$-dating is a novel method to calculate the relative age of organic substance homologues in soils.

Figure 4. Principle of ${ }^{13} \mathrm{C}$-dating calculation of the relative ages of $\mathrm{C}_{31} n$-alkane homologues in two soil compartments, the humin-encapsulated and the 200$2000 \mu \mathrm{m}$ particle-size fraction, from a soil cultivated 23 years with maize. The kinetic curve refers to equation 2 (Lichtfouse, 1997). Note that the $\mathrm{C}_{31} n$ alkane encapsulated in humin is 6.7 years younger than the $\mathrm{C}_{31} n$-alkane in the bulk soil extract. Note also that the $\mathrm{C}_{31} n$-alkane from the 200-2000 $\mu \mathrm{m}$ particle-size fraction is 25.1 years younger than the $\mathrm{C}_{31} n$-alkane in the bulk soil extract. Those findings demonstrate both physical encapsulation and the occurrence of temporal pools at the molecular level. The wide age difference of 31.8 years between the two $n$-alkane fractions reveals that physical encapsulation can strikingly change the dynamics of a molecular substance.

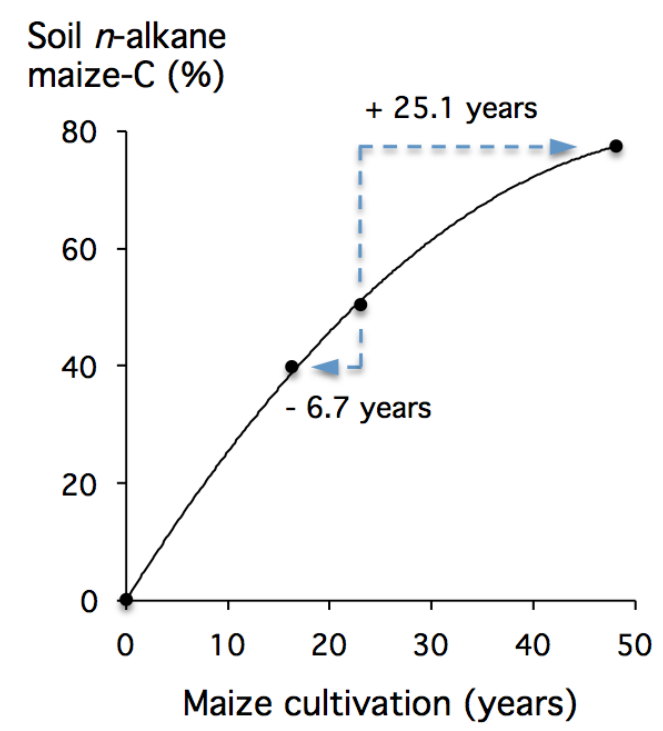




\section{Implications}

${ }^{13} \mathrm{C}$-dating is a method requiring the occurrence of an isotope shift with time, either at natural abundance or by ${ }^{13} \mathrm{C}$-labelling. This method is particularly useful over short-time periods of $0-200$ years where ${ }^{14} \mathrm{C}$-dating is less suitable. ${ }^{13} \mathrm{C}$ dating is applicable to study individual substances from complex media such as soils, palaeosols, sediments, sewage sludge's, and organic matter from waters and airborne particulates. Noteworthy, ${ }^{13} \mathrm{C}$ dating should not be used to measure absolute ages because ${ }^{13} \mathrm{C}$ dating is based on kinetic modelling. Concerning climate change ${ }^{13} \mathrm{C}$-dating should be particularly useful to identify molecular compounds and associatedfractions that sequester carbon over decades to centuries. A such knowledge would indeed help to define sustainable agricultural systems that are sequestrating carbon. ${ }^{13} \mathrm{C}$-dating can also be applied to study the mechanisms of pollutant trapping in complex environmental samples(Lichtfouse et al., 1998b). Such knowledge would be useful to understand for example why herbicides are still released in waters years after the herbicide ban(Barth et al. 2009). Understanding pollutant trapping at the molecular level is also needed to define agricultural practices that reduce the use of pesticides (Alletto et al., 2010). ${ }^{13} \mathrm{C}$ dating can also be used to study the turnover of substances in biological samples (Lichtfouse, 2000). For instance this non-radioactive technique would allow to investigate the metabolism of naturally ${ }^{13} \mathrm{C}$-enriched maize-derived food substances or ${ }^{13} \mathrm{C}$-tagged pharmaceuticals and food substances in the human body and other living organisms. Indeed the concept of encapsulation is highly relevant to medicine and food science (Mishra et al., 2010, Fang and Bhandari 2010).

\section{Conclusion}

${ }^{13} \mathrm{C}$-dating allows to calculate the relative age of substance homologues occurring in various pools from the same sample. Results show large variations from -6.7 to +25.1 years of the relative age of the $\mathrm{C}_{31} n$-alkane in 6 fractions from the same soil sample. Such wide age difference of 31.8 years reveals that physical encapsulation can strikingly change the dynamics of a molecular substance.${ }^{13} \mathrm{C}$-dating will thus be useful to identify substances and associated fractions that sequester carbon in soils. ${ }^{13} \mathrm{C}$-dating is potentially applicable to study the dynamics of organic substances occurring in complex media subjected to an isotope shift over time, such as sediments, water, sludge's, airborne particulates and biological samples. ${ }^{13} \mathrm{C}$-dating is also potentially applicable to study the delayed release of molecular substances in medicine and food science. 


\section{References}

Alletto L, Coquet Y, Benoit P, Heddadj D, Barriuso E (2010) Tillage management effects on pesticide fate in soils. A review. Agron Sustain Dev 30: 367-400. doi: 10.1051/agro/2009018

Barriuso E, Benoit P, Dubus IG (2008) Formation of pesticide nonextractable (bound) residues in soil: magnitude, controlling factors and reversibility. Environ Sci Technol 42 : 1845-1854.doi:10.1021/es7021736

Barth JAC, Grathwohl P, Fowler HJ, Bellin A, Gerzabek MH, Lair GJ, Barceló D, Petrovic M, Navarro A, Négrel Ph, Petelet-Giraud E, Darmendrail D, Rijnaarts H, Langenhoff A, de Weert J, Slob A, van der Zaan BM, Gerritse J, Frank E, Gutierrez A, Kretzschmar R, Gocht T, Steidle D, Garrido F, Jones KC, Meijer S, Moeckel C, Marsman A, Klaver G, Vogel T, Bürger C, Kolditz O, Broers HP, Baran N, Joziasse J, Von Tümpling W, Van Gaans P, Merly C, Chapman A, Brouyère S, Batlle Aguilar J, Orban Ph, Tas N, Smidt H (2009) Mobility, turnover and storage of pollutants in soils, sediments and waters: achievements and results of the EU project AquaTerra. A review. Agron Sustain Dev29: 161173. doi : 10.1051/agro:2007060

Benbi DK, Brar JS (2009) A 25-year record of carbon sequestration and soil properties in intensive agriculture. Agron Sustain Dev 29: 257-265. doi: 10.1051/agro/2008070

Bull ID, van Bergen PF, Nott CJ, Poulton PR, Evershed RP (2000) Organic geochemical studies of soils from the Rothamsted classical experiments-V. The fate of lipids in different long-term experiments. Org Geochem $31: 389$ 408. doi:10.1016/S0146-6380(00)00008-5

Cayet C, Lichtfouse E (2001) $\delta^{13} \mathrm{C}$ of plant-derived $n$-alkanes in soil particle-size fractions. Org Geochem 32:253-258. doi:10.1016/S0146-6380(00)00172-8

Doumbia M, Jarju A, Sène M, Traoré K, Yost R, Kablan R, Brannan K, Berthe A, Yamoah C, Querido A, Traoré PCS, Ballo A (2009) Sequestration of organic carbon in West African soils by Aménagement en Courbes de Niveau. Agron Sustain Dev $29: 267-275$. doi: 10.1051/agro:2008041

Fang Z, Bhandari B (2010) Encapsulation of polyphenols - a review. Trends Food Sci Techn 21: 510-523. doi:10.1016/j.tifs.2010.08.003

Freier K, Glaser B, Zech W (2010) Mathematical modeling of soil carbon turnover in natural Podocarpus forest and Eucalyptus plantation in Ethiopia using compound specific $\delta^{13} \mathrm{C}$ analysis

Global Change Biol: 16, 1487-1502. doi: 10.1111/j.1365-2486.2009.02096.x

Gleixner G, Poirier N, Bol R, Balesdent J (2002) Molecular dynamics of organic matter in a cultivated soil. Org Geochem 33: 357-366. doi:10.1016/S0146-6380(01)00166-8

Halberg N, Hermansen JE, Kristensen IS, Eriksen J, Tvedegaard N, Petersen BM (2010) Impact of organic pig production systems on $\mathrm{CO}_{2}$ emission, $\mathrm{C}$ sequestration and nitrate pollution. Agron Sustain Dev 30: 721-731. doi: 10.1051/agro/2010006

Harkness DD, Harrison AF, Bacon PJ (1986) The temporal distribution of 'bomb' ${ }^{14} \mathrm{C}$ in a forest soil. Radiocarbon 28: 328-337

Hazarika S, Parkinson R, Bol R, Dixon L, Russell P, Donovan S, Allen D (2009) Effect of tillage system and straw management on organic matter dynamics. Agron Sustain Dev 29: 525-533. doi: 10.1051/agro/2009024

Hedges JI, Eglinton G, Hatcher PG, Kirchman DL, Arnosti C, Derenne S, Evershed RP, Kögel-Knabner I, de Leeuw JW, Littke R., Michaelis W, Rullkötter J (2000) The molecularly-uncharacterized component of nonliving organic matter in natural environments. Org Geochem 31: 945-958. doi:10.1016/S0146-6380(00)00096-6

Hedges JI, Oades JM (1997) Comparative organic geochemistries of soils and marine sediments. Org Geochem 27: 319-361. doi:10.1016/S0146-6380(97)00056-9

Huang Y, Eglinton G, Ineson P, Latter PM, Bol R, Harkness DD (1997) Absence of carbon isotope fractionation of individual $n$-alkanes in a 23-year field decomposition experiment with Calluna vulgaris. Org Geochem 26: 497-501. doi:10.1016/S0146-6380(97)00027-2

Knicker H, Hatcher PG (1997) Survival of protein in an organic-rich sediment: possible protection by encapsulation in organic matter. Naturwissenschaft 84: 231-234. doi:10.1007/s001140050384 
Kubicki JD, Apitz SE (1999) Models of natural organic matter and interactions with organic contaminants. Org Geochem 30: 911-927. doi:10.1016/S0146-6380(99)00075-3

Lal R (2010) Soils as source and sink of environmental carbon dioxide. In: Xu J and Huang PM (eds) Molecular Environmental Soil Science at the Interfaces in the Earth's Critical Zone. Springer, Berlin, pp 11-12. doi:10.1007/9783-642-05297-2_3

Lichtfouse $\mathrm{E}(1995){ }^{13} \mathrm{C}$ Labelling of soil $n$-hentriacontane $\left(\mathrm{C}_{31}\right)$ by maize cultivation. Tetrahedron Lett 36 : $529-530$. doi:10.1016/0040-4039(94)02305-U

Lichtfouse E (1997) Heterogeneous turnover of molecular organic substances from crop soils as revealed by ${ }^{13} \mathrm{C}$ labeling at natural abundance with Zea mays. Naturwissenschaft 84: 23-25. doi: 10.1007/s001140050342

Lichtfouse E (1999) Temporal pools of individual organic substances in soil. Analusis27, 442-444. oai:hal.archivesouvertes.fr:hal-00262449. http://hal.archives-ouvertes.fr/hal-00262449/fr/

Lichtfouse E (2000) Compound-specific isotope analysis (CSIA). Application to archaeology, biomedical sciences, biosynthesis, environment, extraterrestrial chemistry, food science, forensic science, humic substances, microbiology, organic geochemistry, soil science and sport. Rapid Commun. Mass Spectrom. 14: 1337-1344.

doi: 10.1002/1097-0231(20000815)14:15<1337::AID-RCM9>3.0.CO;2-B

Lichtfouse E, Chenu C, Baudin F, Leblond C, Da Silva M, Behar F, Derenne S, Largeau C, Wehrung P, Albrecht P (1998a) A novel pathway of soil organic matter formation by selective preservation of resistant straight-chain biopolymers: chemical and isotope evidence.

Org Geochem 28: 411-415. doi: 10.1016/S0146-6380(98)00005-9

Lichtfouse E, Hamelin M, Navarrete M, Debaeke P, Henri A (2010) Emerging agroscience. Agron. Sustain Dev 30 : 1 10. doi: 10.1051/agro/2009055

Lichtfouse E, Hamelin M, Navarrete M, Debaeke P (2011) Sustainable Agriculture Volume 2. Springer Netherlands, 991 p. doi: 10.1007/978-94-007-0394-0

Lichtfouse E, Navarrete M, Debaeke P, Souchère V, Alberola C (2009) Sustainable Agriculture. Springer Netherlands, 919 p. doi: 10.1007/978-90-481-2666-8

Lichtfouse E, Wehrung P, Albrecht P (1998b) Plant wax $n$-alkanes trapped in soil humin by noncovalent bonds. Naturwissenschaft 85: 449-452. doi: 10.1007/s001140050529

Marschner B, Brodowski S, Dreves A, Gleixner G, Gude A, Grootes PM, Hamer U, Heim A, Jandl G, Ji R, Kaiser K, Kalbitz K, Kramer C, Leinweber P, Rethemeyer J, Schäffer A, Schmidt MWI, Schwark L, Wiesenberg GLB (2008) How relevant is recalcitrance for the stabilization of organic matter in soils? J Plant Nutr Soil Sci,171: 91-110. doi: 10.1002/jpln.200700049

Mazeas L, Budzinski H, Raymond N (2002) Absence of stable carbon isotope fractionation of saturated and polycyclic aromatic hydrocarbons during aerobic bacterial biodegradation. Org Geochem 33: 1259-1272. doi:10.1016/S01466380(02)00136-5

Mishra B, Patel BB, Tiwari S (2010) Colloidal nanocarriers: a review on formulation technology, types and applications toward targeted drug delivery. Nanomed Nanotech Biol Med 6: 9-24. doi:10.1016/j.nano.2009.04.008

Novak SM, Fiorelli JL (2010) Greenhouse gases and ammonia emissions from organic mixed crop-dairy systems: a critical review of mitigation options. Agron Sust Dev 30:215-236. doi: 10.1051/agro/2009031

Ohkouchia N, Eglinton R (2008) Compound-specific radiocarbon dating of Ross Sea sediments: A prospect for constructing chronologies in high-latitude oceanic sediments. Quatern Geochron 3, 235-243. doi:10.1016/j.quageo.2007.11.001

Pati FM, Clay DE, Carlson G, Clay SA (2010) Non-isotopic and ${ }^{13} \mathrm{C}$ isotopic approaches to calculate soil organic carbon maintenance requirement. In Lichtfouse E (ed) Sociology, Organic Farming, Climate Change and Soil Science. Sustain Agric Rev 3, 189-215. doi: 10.1007/978-90-481-3333-8_8 
Pearson A, Eglinton TI (2000) The origin of n-alkanes in Santa Monica Basin surface sediment: a model based on compound-specific $\Delta 14 \mathrm{C}$ and $\delta 13 \mathrm{C}$ data Org Geochem 31: 1103-1116. doi:10.1016/S0146-6380(00)00121-2

Pearson A, McNichol AP, Benitez-Nelson BC, Hayes JM, Eglinton TI (2001) Origins of lipid biomarkers in Santa Monica Basin surface sediment: a case study using compound-specific $\Delta^{14} \mathrm{C}$ analysis. Geochim Cosmochim Acta 65 : 3123-3137.doi:10.1016/S0016-7037(01)00657-3

Rubino M, Dungait JAJ, Evershed RP, Bertolini T, De Angelis P, D’Onofrio A, Lagomarsino A, Lubritto C, Merola A, Terrasi F, Cotrufo MF (2010) Carbon input belowground is the major C flux contributing to leaf litter mass loss: Evidences from a ${ }^{13} \mathrm{C}$ labelled-leaf litter experiment. Soil Biol Biochem 42: 1009-1016.

doi:10.1016/j.soilbio.2010.02.018

Schnitzer M (1991) Soil organic matter - the next 75 years. Soil Science 151: 41-58.

Sohi SP, Krull E, Lopez-Capel E, Bol R (2010) A review of biochar and its use and function in soil. Adv Agronomy 105: 47-82. doi:10.1016/S0065-2113(10)05002-9

Stavi I, Lal R (2011) Challenges and Opportunities of Soil Organic Carbon Sequestration in Croplands. In Lichtfouse E (ed) Biodiversity, Biofuels, Agroforestry and Conservation Agriculture.

Sust Agric Rev 5: 149-174. doi:10.1007/978-90-481-9513-8_5

Sun Y, Chen Z, Xu S, Cai P (2005) Stable carbon and hydrogen isotopic fractionation of individual $n$-alkanes accompanying biodegradation: evidence from a group of progressively biodegraded oils. Org Geochem 36: $225-238$. doi:10.1016/j.orggeochem.2004.09.002

Sutton R, Sposito G (2005) Molecular structure in soil humic substances: the new view.

Environ Sci Technol 39 : 9009-9015. doi: 10.1021/es050778q

Trumbore S (2000) Age of soil organic matter and soil respiration: radiocarbon contraints on belowground C dynamics. Ecological Applic 10: 399-411.

doi:10.1890/1051-0761(2000)010[0399:AOSOMA]2.0.CO;2

Wan Y, Amundson R, Trumbore S (1996) Radiocarbon dating of soil organic matter. Quaternary Res 45: $282-288$.

Wiesenberg GLB, Jan Schwarzbauer J, Schmidt MWI, Schwark L (2004) Source and turnover of organic matter in agricultural soils derived from $n$-alkane/ $n$-carboxylic acid compositions and C-isotope signatures. Org Geochem 35 : 1371-1393. doi:10.1016/j.orggeochem.2004.03.009 